\title{
Previous cholecystecto- my and choledochal sphincter spasm after morphine sedation
}

Anthony M.-H. Ho MD MSc FRCPC

Purpose: To describe a patient with probable choledochal sphincter spasm after preoperative morphine, and to suggest a history of cholecystectomy as a predisposing factor.

Clinical features: A 60 yr old man for femoral-popliteal artery bypass grafting developed right upper quadrant abdominal pain after preoperative morphine and scopolamine. He had a previous cholecystectomy. His pain was relieved with naloxone.

Conclusion: Choledochal sphincter spasm should be part of a differential diagnosis in right upper quadrant pain after sedative doses of morphine, especially if there is a previous cholecystectomy.

Objectif : Décrire un cas de spasme du sphincter cholédocien faisant suite à la prise de morphine préopératoire et suggérer que des antécédents de cholécystectomie soient un facteur prédisposant.

Éléments cliniques : Un homme de 60 ans, admis pour un pontage de l'artère fémoro-poplité a développé une douleur abdominale au quadrant supérieur droit après avoir pris de la morphine et de la scopolamine préopératoires. Il avait subi auparavant une cholécystectomie. Sa douleur a été soulagée avec la naloxone.

Conclusion : Le spasme du sphincter cholédocien devrait figurer au diagnostic différentiel lors de douleur abdominale au quadrant supérieur droit après avoir reçu des doses sédatives de morphine, surtout s'il y a eu déjà une cholécystectomie.

From the Department of Anaesthesia and Intensive Care, Prince of Wales Hospital and Faculty of Medicine, The Chinese University of Hong Kong, Shatin, NT, Hong Kong, PRC.

Address correspondence to: Dr. Anthony Ho, Phone: 852-2632-2735; Fax: 852-2637-2422; E-mail: hoamh@hotmail.com Accepted for publication September 6, 1999 
$\mathrm{T}$ HE differential diagnosis of right upper quadrant abdominal pain includes important thoracic and abdominal problems. Spasm of the choledochal sphincter (CS) causes right upper quadrant abdominal pain. ${ }^{1}$ Opioids can induce CS spasm, with fentanyl being the worst offender. ${ }^{2}$ Once problems such as coronary insufficiency have been excluded, CS spasm should be considered when typical pain occurs after opioid pre-medication, especially if the patient has had a previous cholecystectomy.

\section{Case report}

A $60 \mathrm{yr}$ old, $72 \mathrm{~kg}$ man was booked for femoralpopliteal bypass. He had a history of hypertension and smoking, but denied coronary insufficiency or diabetes. He had a cholecystectomy $25 \mathrm{yr}$ previously for colic and had otherwise not taken opioids. He was receiving captopril. Examination revealed a blood pressure of $185 / 95 \mathrm{mmHg}$, heart rate of $85 \mathrm{bpm}$, respiration of 20 breaths. $\mathrm{min}^{-1}$, and mild emphysema. Preoperative ECG contained non-specific ST-T wave changes. He requested preoperative sedation.

The patient received $10 \mathrm{mg}$ morphine, $0.4 \mathrm{mg}$ scopolomine, $i m$, one hour before surgery. Forty minutes later, he complained of sharp right upper quadrant pain with radiation to the back below the right scapula, and slight nausea. It was similar to his gallbladder attacks many years ago. On examination, the patient was restless. Vital signs were unchanged and abdominal examination revealed no abnormalities and did not exacerbate his pain. Blood taken at that time was reported later to contain normal levels of liver and cardiac enzymes, alkaline phosphatase, and bilirubin. His ECG and Chest X-ray revealed no acute problems. A test dose of $0.05 \mathrm{mg}$ naloxone iv resulted in slight but definite improvement of his pain. A further dose of $0.1 \mathrm{mg}$ naloxone resulted in further improvement. Complete relief was achieved after a total of $0.4 \mathrm{mg}$ over $10 \mathrm{~min}$. About $15 \mathrm{~min}$ later, the pain recurred, and he required small aliquots of naloxone to a total of $0.4 \mathrm{mg}$ before the pain subsided. By this time, the diagnosis of probable CS spasm had been made and the patient was taken to the operating room where an epidural anesthetic was planned. Another 15 min after the last dose of naloxone, his pain recurred and was finally controlled with an additional dose of $0.1 \mathrm{mg}$ naloxone. A lumbar epidural catheter was inserted uneventfully and $3 \mathrm{ml}$ lidocaine $2 \%$ with epinephrine $1 / 200,000$ and $11 \mathrm{ml}$ bupivacaine $0.5 \%$ were used to produce surgical anesthesia.

Postoperatively he was maintained for $48 \mathrm{hr}$ with an infusion of bupivacaine $0.2 \%$ at $7-10 \mathrm{ml} \cdot \mathrm{hr}^{-1}$ for pain control. He did not suffer any further right upper quadrant pain during the rest of his hospital stay. Serial postoperative ECGs revealed no changes. He recovered from his surgery with no complication.

\section{Discussion}

This case was one of several similar cases in this author's experience. Bird ${ }^{3}$ has described a case of probable CS spasm in a $27 \mathrm{yr}$ old woman after pre-medication with $15 \mathrm{mg}$ papaveretum and $0.3 \mathrm{mg}$ hyoscine; she too had a previous cholecystectomy. This author has not encountered a case of clinical CS spasm in the immediate postoperative period, and found no such report in the literature.

The apparent predisposition to CS spasm of patients with previous cholecystectomy after preoperative opioid sedation has important anesthetic implications, and deserves an explanation.

Asymptomatic gallstones are common, but when CS dysfunction leads to biliary symptoms, management often includes cholecystectomy. In other words, CS spasm-susceptible people may more likely to have had a cholecystectomy than non-susceptible people.

It is also possible that the absence of a gallbladder exacerbates CS spasm-induced common bile duct hypertension. The biliary system is highly innervated with pain fibres. ${ }^{4}$ The pain of CS spasm is not necessarily from the spasm itself but is due to the resultant common bile duct distention. ${ }^{1}$ Mengay et al..$^{5}$ found, in cholecystectomized dogs, that the absence of a normally distensible gallbladder resulted in much higher biliary pressure than in intact dogs when opioidinduced CS spasm occurs.

Another mechanism of increased CS spasm in postcholecystectomized patients may be disruption of nerve fibres (that inhibit CS spasm) that pass between the gallbladder and the CS via the cystic duct. 6,7

Opioids are used more frequently after than before surgery. Yet, CS spasm is rare in the immediate postoperative period. One explanation is the development of tachyphylaxis to the spasmogenic effects of opioids in the biliary system, ${ }^{8,9}$ and the resulting spasm is relatively transient. In addition, while analgesia is proportional to opioid dosage, the maximum opioid-induced pain of CS spasm is reached once the CS closes and biliary ductal pressure plateaus. With the large doses of opioids used intraoperatively and for postoperative analgesia, the pain from CS spasm-induced ductal hypertension, if it occurs, is easily masked by the opioids and by the discomfort caused by the operation. The small preoperative sedative dose of opioids, on the other hand, is enough to induce CS spasm but inadequate to mask the resulting pain. Since preoperative sedation, especially 
with opioids, is uncommon nowadays, this problem is likely to occur very infrequently.

Although anti-cholinergics should relieve CS spasm, the concomitant administration of scopolomine did not completely prevent the spasm. Nalbuphine, an opioid with $\mu$-receptor antagonistic properties, may be a useful alternative to naloxone. ${ }^{10}$ Other drugs that can potentially relieve CS spasm include glucagon, calcium channel blockers, aminophylline, and nitrates.

In summary, choledochal sphincter spasm may be more likely to occur in patients with previous cholecystectomy, and may accompany smaller doses of morphine or other opioids, and may not be relieved with the concomitant use of scopolamine. The pain appears highly responsive to naloxone, which normally aggravates most other pain. When used with caution, therefore, naloxone can serve both diagnostic and therapeutic purposes. An increased awareness of CS spasm can at times avoid unnecessary work up and case postponement. Opioids are not the drugs of choice for most situations requiring preoperative sedation, especially in patients with previous cholecystectomy.

Acknowledgement

The author thanks Dr. Janet Lee of the Prince of Wales Hospital, Hong Kong, for her helpful comments.

\section{References}

l Chuttani R, Carr-Locke DL. Pathophysiology of the sphincter of Oddi. Surg Clin N Am 1997; 73 : 1311-22.

2 Radnay PA, Duncalf D, Novakovic N, Lesser ML. Common bile duct pressure changes after fentanyl, morphine, meperidine, butorphanol, and naloxone. Anesth Analg 1984; 63: 441-4.

3 Bird KJ. Narcotic-induced choleduchoduodenal sphincter spasm reversed by naloxone. Anaesthesia 1986; 41: 1120-3.

4 Britton J, Bickerstaff KI, Savage A Benign diseases of the biliary tract. In: Morris PJ, Malt RA (Eds.). Oxford Textbook of Surgery. New York: Oxford University Press, 1994: 1209-39.

5 Menguy RB, Hallenbeck GA, Bollman JL, Grindlay JH. Pancreatic and biliary intraductal pressures. Surg Forum 1955; 6: 359-63.

6 Rolny P, Funch-Jensen P, Kruse A, Thommesen P. Effect of cholecystectomy on the relationship between hydrostatic common bile duct pressure and sphincter of Oddi motility. Endoscopy 1991; 23: 111-3.

7 Grace PA, Pitt HA. Cholecystectomy alters the hormonal response of the sphincter of Oddi. Surgery 1987; 102: 186-94.
8 Crema A, Benzi G, Frigo GM, Berte F. The response of the terminal bile duct to morphine and morphine-like drugs. J Pharmacol Exp Ther 1965; 149: 373-8.

9 Greenstein AJ, Kaynan A, Singer A, Dreiling DA. A comparative study of pentazocine and meperidine on the biliary passage pressure. Am J Gastroenterol 1972; 58: 417-27.

10 Humphreys HK, Fleming NW. Opioid-induced spasm of the sphincter of Oddi apparently reversed by nalbuphine. Anesth Analg 1992; 74: 308-10. 